\title{
Jenkins Model Based Magnetic Squeeze Film In Curved Rough Circular Plates Considering Slip Velocity: A Comparison Of Shapes
}

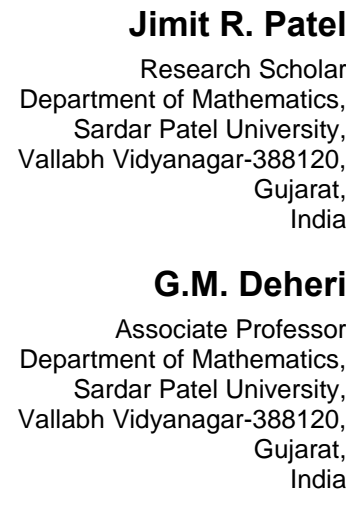

Jimit R. Pate partment of Mathematics, Sardar Patel University, Gujarat India

G.M. Deheri Sardar Patel University, Gujarat India
An endeavour has been made to compare the performance of a Jenkins model based magnetic squeeze film in curved rough circular plates considering slip velocity for different shapes of the surfaces. Three different shapes (exponential, hyperbolic, secant) have been taken for comparison. Beavers and Joseph's slip model has been considered to analyze the effect of slip. The statistical averaging model of Christensen and Tonder has been adopted to study the effect of surface roughness. The concerned generalized Reynolds type equation is solved to obtain pressure distribution leading to the calculation of load carrying capacity. The results presented in graphical forms establish that Jenkins model modifies the performance in the case of Neuringer-Rosensweig model. The Jenkins model based ferrofluid lubrication moves to a certain extent in reducing the adverse effect of roughness and slip velocity. The extent is more in the case of exponential shape. It is interesting to note that for the exponential shape the combined effect of magnetism and negatively skewed roughness is relatively more, even for higher values of slip parameter.

Keywords: Jenkins model, Curved Circular plates, Roughness, Magnetic Fluid, slip velocity.

\section{INTRODUCTION}

Ferrofluid, a kind of stable colloid mainly, consisting of magnetic nano particles, surfactant and liquid carrier, has both the magnetism of solid magnetic material and fluidity of liquid. One of the most important properties of the magnetic fluid is that it can be retained at a desired location by an external magnetic field. Owing to the properties of magnetic fluid, it is found to be useful in engineering, science and biomedical applications. Ferrofluid is also used in sealing of hard disc drives, rotating-ray tubes under engineering application. The flow behaviour of magnetic fluids has been analytically studied, basically, by using two models, one given by Neuringer- Rosensweig and the other one proposed by Shliomis. Later on, Jenkins modified the model of Neuringer- Rosensweig. A number of authors [1-8] have discussed the applications and theory of ferrofluids. [912] analyzed the steady-state performance of bearings with Jenkins model based magnetic fluid flow. It was manifest that the load carrying capacity of bearing system increased with increasing magnetization of the magnetic fluid.

The squeeze film performance between different geometrical configurations is discussed in a number of investigations [13-17]. [17-22] dealt with the effect of curvature parameters on the performance of squeeze film in rough plates.

Received: October 2014 Accepted: April 2015

Correspondence to: Jimit R. Patel

Department of Mathematics, Sardar Patel University,

Vallabh Vidyanagar-388120, Gujarat, India.

E-mail: patel.jimitphdmarch2013@gmail.com

doi:10.5937/fmet1502144P

(C) Faculty of Mechanical Engineering, Belgrade. All rights reserved
Reduction of friction is quite essential for the effective performance of a bearing system. It is investigated that slip velocity supports to reduce the friction. Beavers and Joseph [23] studied the interface between a porous medium and fluid layer in an experimental study and proposed a slip boundary condition at the interface. Flow with slip becomes useful for problems in chemical engineering for example, flows through pipes in which chemical reactions occur at the walls. [24] analyzed the performance of hydro-magnetic squeeze film between porous circular disks with velocity slip. Many investigations have discussed theoretically and experimentally the effects of slip on various types of bearings [25-31] and [12]. In all the above studies, it was found that the slip effect significantly affected the bearing system. [32] analyzed the effects of velocity slip and viscosity variation in squeeze film lubrication of two circular plates. Recently, [33] investigated the performance of slip Velocity and roughness on magnetic fluid based infinitely long bearings.

In all the above studies bearing surfaces were considered to be smooth. But it is unrealistic because, the bearing surfaces develop roughness after having some run-in and wear. Several methods have been mooted to deal with the effect of surface roughness on the performance characteristics of squeeze films. [3436] modified the stochastic model of [37] to study the effect of surface roughness in general. A number of investigations adopted the stochastic model of [34-36] to study the effect of surface roughness [38-49]. [50] studied the effects of various porous structures on the performance of a Shliomis model based ferrofluid lubrication of a squeeze film in rotating rough porous curved circular plates. It was noticed that the adverse 
effect of transverse roughness could be overcome by the positive effect of ferrofluid lubrication in the case of negatively skewed roughness by suitably choosing curvature parameters and rotational inertia when Kozeny- Carman's model was deployed for porous structure. [51] theoretically analyzed the effect of Shliomis model based ferrofluid lubrication on the squeeze film between curved rough annular plates with comparison between two different porous structures. It was shown that the effect of morphology parameter and volume concentration parameter increased the load carrying capacity.

The objective of this study is to theoretically compare the performance for various geometrical shapes of surface on the behaviour of a squeeze film in rough curved circular plates considering slip velocity and Jenkins model based ferrofluid lubrication.

\section{ANALYSIS}

The bearing configuration consists of two circular plates separated by a lubrication film, each of radius $a$. The bearing geometry is displayed in Figure 1.

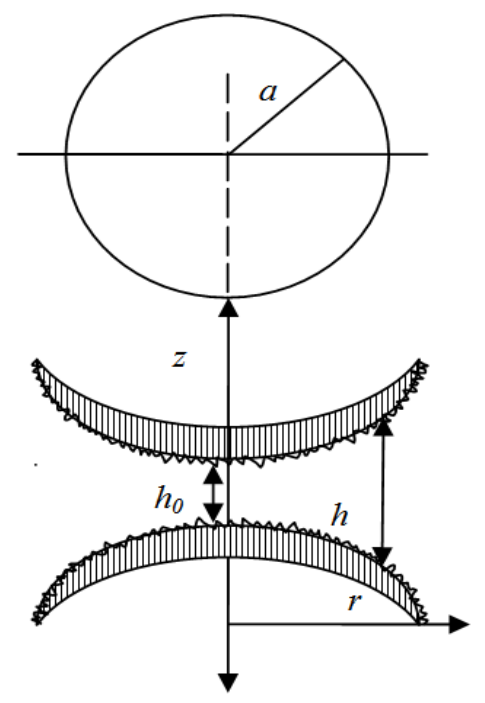

Figure 1. Configuration of the bearing system

The bearing surfaces are considered transversely rough. According to the stochastic theory of [34-36], the thickness $h$ of the lubricant film is taken as

$$
h=\bar{h}+h_{\mathrm{s}}
$$

where $\bar{h}$ is the mean film thickness and $h_{s}$ is the deviation from the mean film thickness characterizing the random roughness of the bearing surfaces. $h_{s}$ is governed by the probability density function

$$
f\left(h_{s}\right)=\left\{\begin{array}{c}
\frac{35}{32 c^{7}}\left(c^{2}-h_{s}^{2}\right)^{3},-c \leq h_{s} \leq c \\
0, \text { elsewhere }
\end{array}\right.
$$

wherein $c$ represents the maximum deviation from the mean film thickness. The mean $\alpha$, the standard deviation $\sigma$ and the parameter $\varepsilon$ which is the measure of symmetry of the random variable $h_{s}$, are defined and discussed in [34-36].
To study the quantitative effect of surface roughness of the bearing on its performance characteristics three different lubricant film shapes for the curved circular plates bearing are considered. In the light of [17] and [52-53], the following shapes are considered

[I] The upper plate lying along the surface governed by

$$
z_{u}=h_{0} \exp \left(-\beta r^{2}\right) ; 0 \leq r \leq a
$$

approaches with normal velocity $\dot{h}_{0}$ to the lower plate lying along the surface specified by

$$
z_{l}=h_{0}\left[\exp \left(-\gamma r^{2}\right)-1\right] ; 0 \leq r \leq a
$$

[II] The upper plate lying along the surface described by

$$
z_{u}=h_{0}\left[\frac{1}{1+\beta r}\right] ; 0 \leq r \leq a
$$

approaches with normal velocity $\dot{h}_{0}$ to the lower plate lying along the surface given by

$$
z_{l}=h_{0}\left[\frac{1}{1+\gamma r}-1\right] ; 0 \leq r \leq a
$$

[III] The upper plate lying along the surface given by

$$
z_{u}=h_{0}\left[\sec \left(\beta r^{2}\right)\right] ; 0 \leq r \leq a
$$

approaches with normal velocity $\dot{h}_{0}$ to the lower plate lying along the surface governed by

$$
z_{l}=h_{0}\left[\sec \left(\gamma r^{2}\right)-1\right] ; 0 \leq r \leq a
$$

where $\beta$ and $\gamma$ denote the curvature parameters of the corresponding plates and $h_{0}$ is the central film thickness. The film thickness then, are respectively determined by $([17,52,54])$,

$$
\begin{gathered}
h(r)=h_{0}\left[\exp \left(-\beta r^{2}\right)-\exp \left(-\gamma r^{2}\right)+1\right] ; 0 \leq r \leq a \\
h(r)=h_{0}\left[\frac{1}{1+\beta r}-\frac{1}{1+\gamma r}+1\right] ; 0 \leq r \leq a
\end{gathered}
$$

and

$$
h(r)=h_{0}\left[\sec \left(\beta r^{2}\right)-\sec \left(\gamma r^{2}\right)+1\right] ; 0 \leq r \leq a
$$

In 1972, a simple model to express the flow of a magnetic fluid was proposed by Jenkins. In this paper the magnetisable liquid was regarded as an anisotropic fluid and added to the motion and the temperature, the vector magnetization density to complete the description of the material. The use of local magnetization as an independent variable allowed Jenkins to treat static and dynamic situation in a uniform fashion and to make a natural distinction between paramagnetic and ferromagnetic fluids. A uniqueness theorem was 
recognized for incompressible paramagnetic fluids and determined that in these materials the magnetization vanished with the applied magnetic field. So the Jenkins model is not only a generalization of the NeuringerRosensweig model but also modifies both the pressure and the velocity of the magnetic fluid.

With Maugin's modification, equations of the model for steady flow are ([55] and [10])

$$
\begin{aligned}
\rho(\bar{q} \nabla) \bar{q}= & -\nabla_{p}+\eta \nabla^{2} \bar{q}+\mu_{0}(\bar{M} \nabla) \bar{H}+\frac{\rho A^{2}}{2} \nabla \\
& \times\left[\frac{\bar{M}}{M} \times\{(\nabla \times \bar{q}) \times \bar{M}\}\right]
\end{aligned}
$$

together with

$$
\nabla \bar{q}=0, \nabla \times \bar{H}=0, \bar{M}=\bar{\mu} \bar{H}, \nabla(\bar{H}+\bar{M})=0
$$

([17]), $\rho$ is the fluid density, $\bar{q}$ is the fluid velocity in the film region, $\bar{H}$ is external magnetic field, $\bar{\mu}$ is magnetic susceptibility of the magnetic fluid, $p$ is the film pressure, $\eta$ is the fluid viscosity, $\mu_{0}$ is the permeability of the free space and $A$ being a material constant. From the above equation one concludes that Jenkins model is a generalization of NeuringerRosensweig model with an additional term

$$
\begin{aligned}
& \frac{\rho A^{2}}{2} \nabla \times\left[\frac{\bar{M}}{M} \times\{(\nabla \times \bar{q}) \times \bar{M}\}\right] \\
= & \frac{\rho A^{2} \bar{\mu}}{2} \nabla \times\left[\frac{\bar{H}}{H} \times\{(\nabla \times \bar{q}) \times \bar{H}\}\right]
\end{aligned}
$$

which modifies the velocity of the fluid. At this point one observes that Neuringer-Rosensweig model modifies the pressure while Jenkins model modifies both the pressure and velocity of the ferrofluid.

Let $(u, v, w)$ be the velocity of the fluid at any point $(r, \theta, z)$ between two solid surfaces, with $O Z$ as axis. Making the assumptions of hydrodynamic lubrication and remembering that the flow is steady and axially symmetric, the equations of motion are

$$
\begin{gathered}
\left(1-\frac{\rho A^{2} \bar{\mu} H}{2 \eta}\right) \frac{\partial^{2} u}{\partial z^{2}}=\frac{1}{\eta} \frac{d}{d r}\left(p-\frac{\mu_{0} \bar{\mu}}{2} H^{2}\right) \\
\frac{1}{r} \frac{\partial}{\partial r}(r u)+\frac{\partial w}{\partial z}=0
\end{gathered}
$$

Solving the above equation (4) under the boundary conditions, $u=0$ when $z=0, h$, one obtains

$$
u=\frac{z(z-h)}{2 \eta\left(1-\frac{\rho A^{2} \bar{\mu} H}{2 \eta}\right)} \frac{d}{d r}\left(p-\frac{\mu_{0} \bar{\mu}}{2} H^{2}\right)
$$

Substituting the value of $u$ in equation (5) and integrating it with respect to $z$ over the interval $(0, h)$ one gets Reynolds type equation for film pressure as

$$
\frac{1}{r} \frac{d}{d r}\left(\frac{h^{3}}{\left(1-\frac{\rho A^{2} \bar{\mu} H}{2 \eta}\right)} r \frac{d}{d r}\left(p-\frac{\mu_{0} \bar{\mu}}{2} H^{2}\right)=12 \eta \dot{h}_{0}\right.
$$

For the stochastic averaging theory of this differential equation, a method has been proposed in [34-36]. Here an attempt has been made to modify this method, which on certain simplifications yields, under the usual assumptions of hydro-magnetic lubrication [17, 56-57] the modified Reynolds type equation,

$$
\frac{1}{r} \frac{d}{d r}\left(\frac{g(h)}{\left(1-\frac{\rho A^{2} \bar{\mu} H}{2 \eta}\right)} r \frac{d}{d r}\left(p-\frac{\mu_{0} \bar{\mu}}{2} H^{2}\right)=12 \eta \dot{h}_{0}\right.
$$

where

$$
\begin{gathered}
g(h)=\left(h^{3}+3 h^{2} \alpha+3\left(\sigma^{2}+\alpha^{2}\right) h+3 \sigma^{2} \alpha+\alpha^{3}+\varepsilon\right) \\
\left(\frac{4+s h}{2+s h}\right)
\end{gathered}
$$

Following dimensionless quantities are considered;

$$
\begin{gathered}
\bar{h}=\frac{h}{h_{0}}, R=\frac{r}{a}, P=-\frac{h_{0}^{3} p}{\eta a^{2} h_{0}}, B=\beta a^{2}, C=\gamma a^{2}, \\
H^{2}=k r^{2} \frac{(a-r)}{a}, \mu^{*}=-\frac{k \mu_{0} \bar{\mu} h_{0}^{3}}{\eta h_{0}}, \bar{\sigma}=\frac{\sigma}{h_{0}}, \\
\bar{A}=\frac{\rho A^{2} \bar{\mu} \sqrt{k} a}{2 \eta}, \bar{\alpha}=\frac{\alpha}{h_{0}}, \bar{\varepsilon}=\frac{\varepsilon}{h_{0}^{3}}, \bar{s}=s h_{0}
\end{gathered}
$$

Using the equation (8), equation (7) transforms to

$$
\begin{gathered}
\frac{1}{R} \frac{d}{d R}\left(\frac{g(\bar{h})}{\left(1-\bar{A}^{2} R \sqrt{1-R}\right)} R \frac{d}{d R}\left(P-\frac{\mu^{*}}{2} R^{2}(1-R)\right)\right) \\
=-12(9)
\end{gathered}
$$

where

$$
\begin{gathered}
g(\bar{h})=\left(\bar{h}^{3}+3 \bar{h}^{2} \bar{\alpha}+3\left(\bar{\sigma}^{2}+\bar{\alpha}^{2}\right) \bar{h}+3 \bar{\sigma} \bar{\alpha}+\bar{\alpha}^{3}+\bar{\varepsilon}\right) \\
\left(\frac{4+\overline{s h}}{2+\bar{s} \bar{h}}\right)
\end{gathered}
$$

Solving equation (9) under the boundary conditions

$$
P(1)=0,\left(\frac{d P}{d R}\right)_{R=0}=0
$$


one derives the expression for the dimensionless pressure distribution as

$$
P=\frac{\mu^{*}}{2} R^{2}(1-R)-6 \int_{1}^{R} \frac{R}{g(\bar{h})}\left(1-\bar{A}^{2} R \sqrt{1-R}\right) d R(11)
$$

The dimensionless load carrying capacity of the bearing system then, is determined by

$$
\begin{gathered}
W=-\frac{h_{0}^{3}}{2 \pi \eta a^{4} h_{0}} w \\
=\int_{0}^{1} R P d R=\frac{\mu^{*}}{40}+3 \int \frac{1}{0} \frac{R^{3}}{g(\bar{h})}\left(1-\bar{A}^{2} R \sqrt{1-R}\right) d R
\end{gathered}
$$

\section{RESULTS AND DISCUSSION}

It can be easily seen that the non-dimensional load carrying capacity gets increased by

$$
\frac{\mu^{*}}{40}
$$

as compared to the case of conventional lubricant based bearing system, for all three geometrical cases. The expression involved in equation (12) is linear with respect to the magnetization parameter and hence an increase in magnetization parameter will lead to increased load carrying capacity. This is not surprising as the magnetization increases the viscosity of the lubricant and consequently, resulting in increased load carrying capacity. It is also found that Jenkins model modifies the performance in the case of NeuringerRosensweig model based magnetic flow.

Besides, the combined effect of surface roughness and slip velocity is relatively adverse. In fact, this investigation makes it clear that for an improved performance of the bearing system the slip parameter is required to be kept at minimum.

Comparison of various shapes, so far as load carrying capacity is concerned, is presented graphically. It can be easily noticed that the situation is fairly good in the case of exponential bearing.

The effect of magnetization on the load carrying capacity presented in Figures 2-6 shows that the load carrying capacity is registered to be more in the case of exponential bearing system.

The fact that material parameter induces an adverse effect is depicted in Figures 7-9. Here, the load carrying capacity is found to be more decreased in all the cases.

The effect of upper plate's curvature parameter on the load carrying capacity is comparatively more in exponential and hyperbolic shapes but this effect is just marginal in the case of secant shape bearing (Figures 10-12).

The fact that the effect of lower plate's curvature parameter on load carrying capacity is almost opposite to that of upper plate's curvature parameter, is found in Figures 13-16. Thus, a judicious choice of both the curvature parameters is required for providing a better performance.

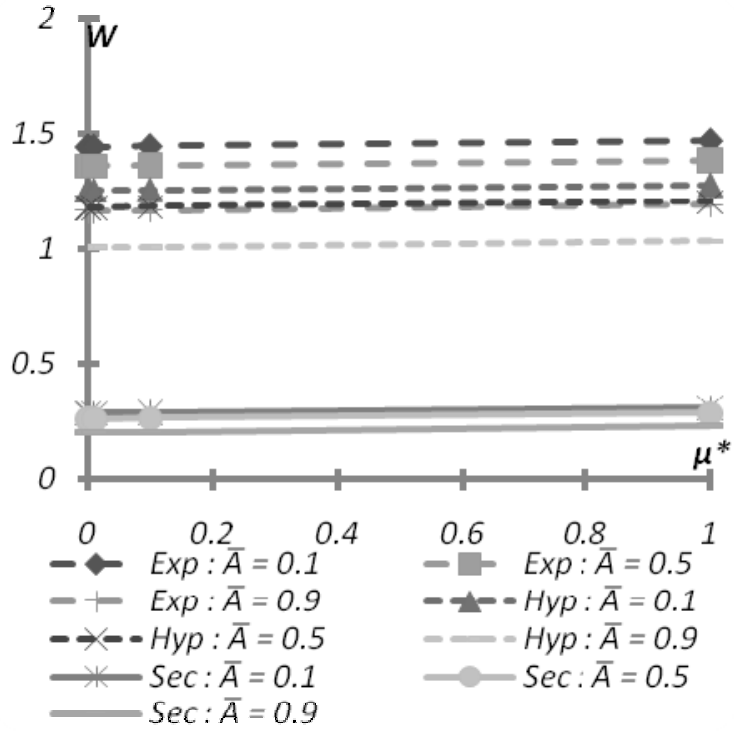

Figure 2. Variation of Load carrying capacity with respect to $\mu^{*}$ and $\bar{A}$.

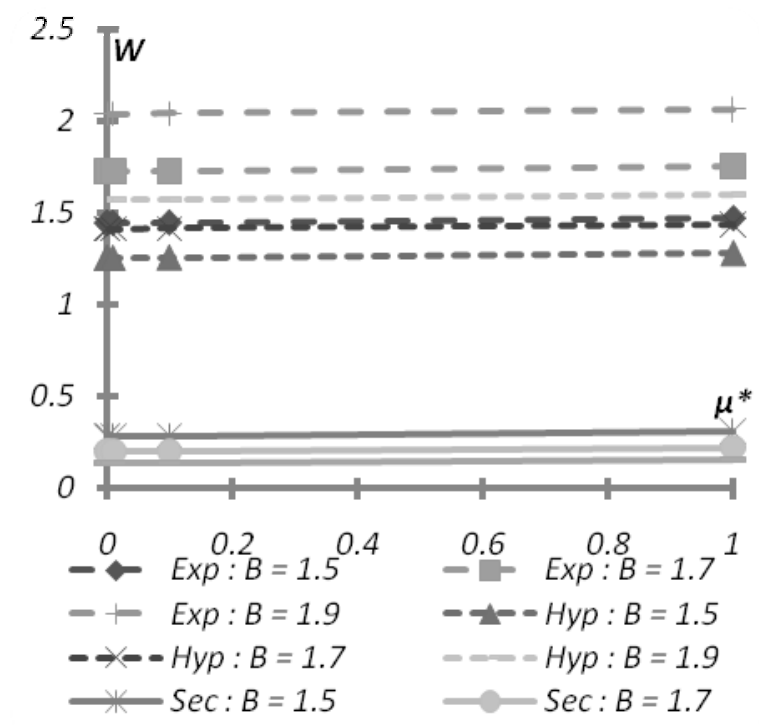

Figure 3. Variation of Load carrying capacity with respect to $\mu^{*}$ and $B$.

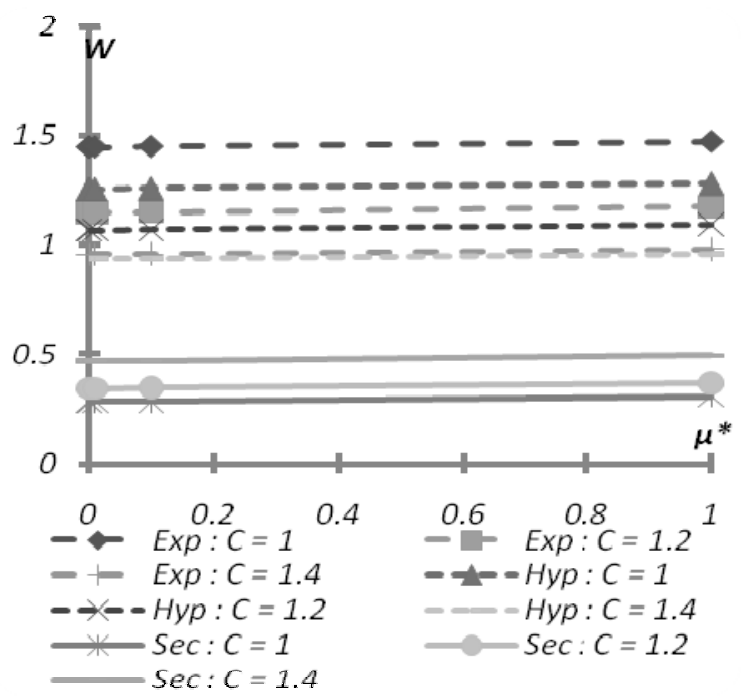

Figure 4. Variation of Load carrying capacity with respect to $\mu^{*}$ and $C$. 


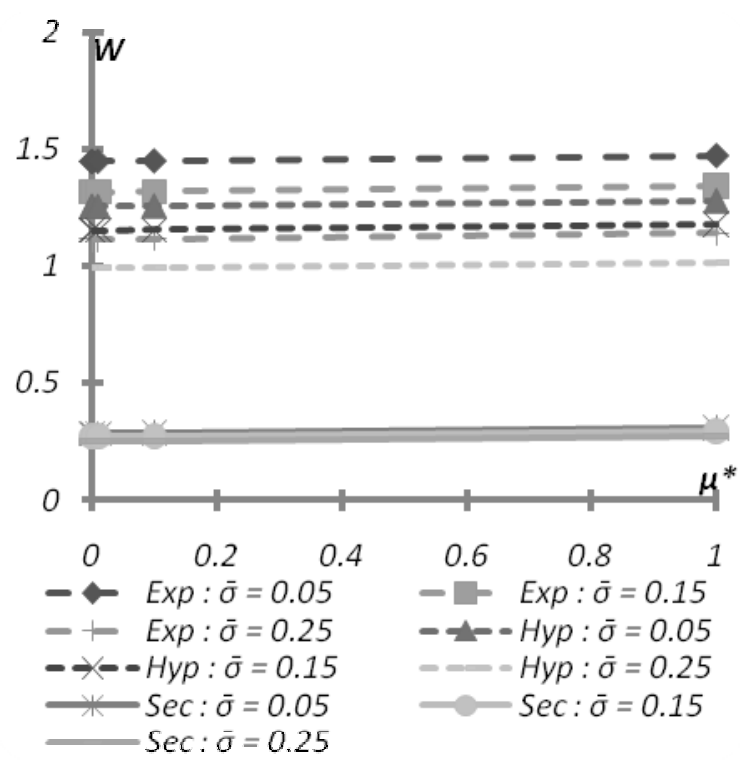

Figure 5. Variation of Load carrying capacity with respect to $\mu^{*}$ and $\bar{\sigma}$.

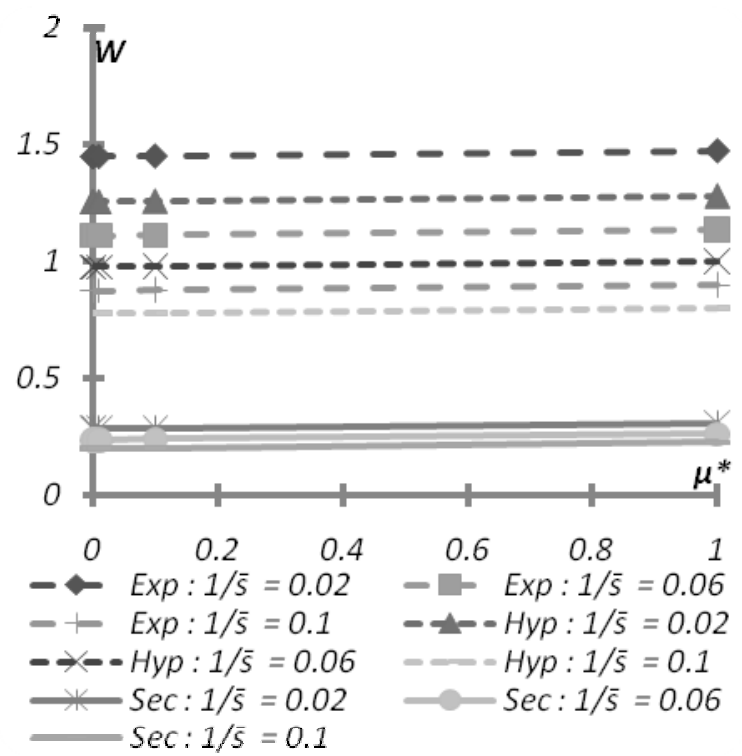

Figure 6. Variation of Load carrying capacity with respect to $\mu^{*}$ and $1 / \bar{s}$.

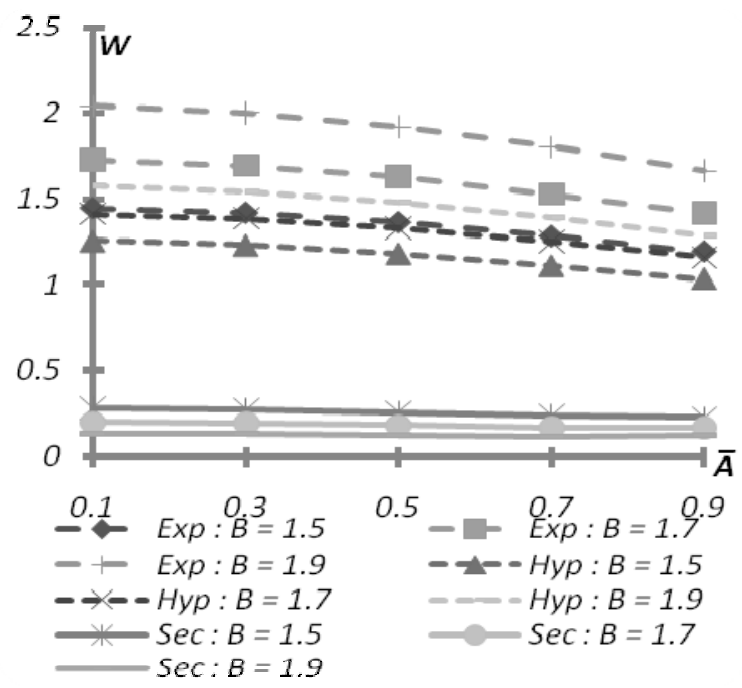

Figure 7. Variation of Load carrying capacity with respect to $\bar{A}$ and $B$.

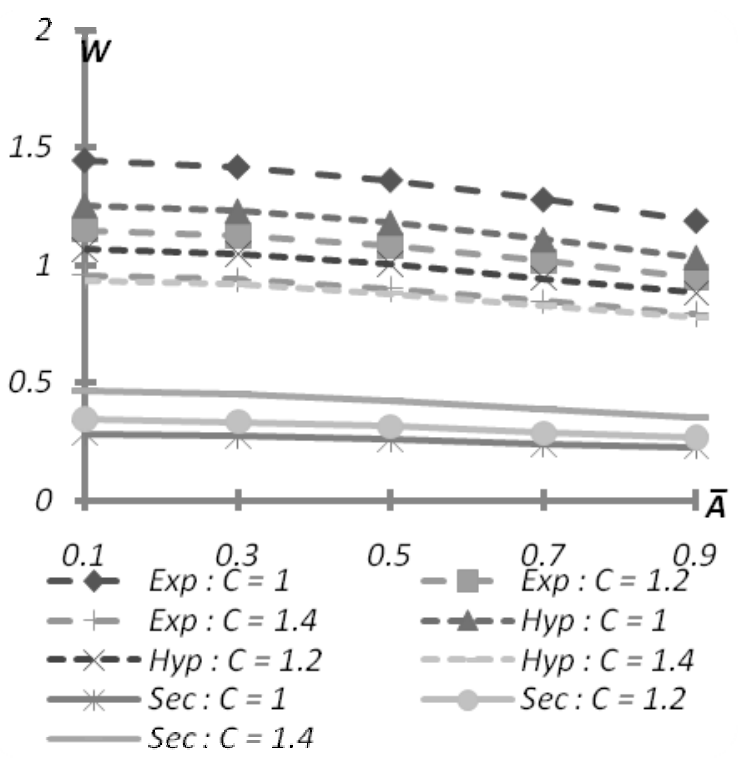

Figure 8. Variation of Load carrying capacity with respect to $\bar{A}$ and $C$.

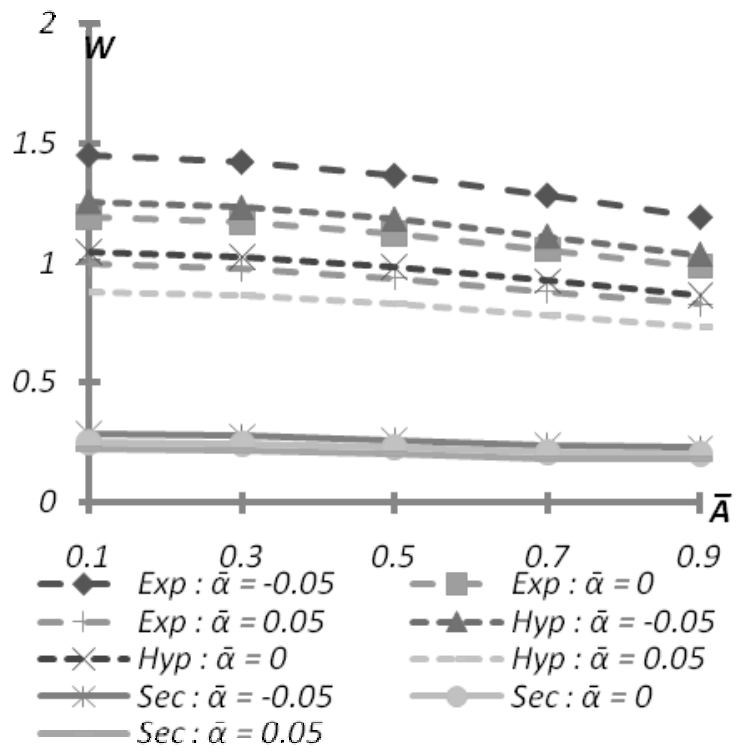

Figure 9. Variation of Load carrying capacity with respect to $\bar{A}$ and $\bar{\alpha}$.

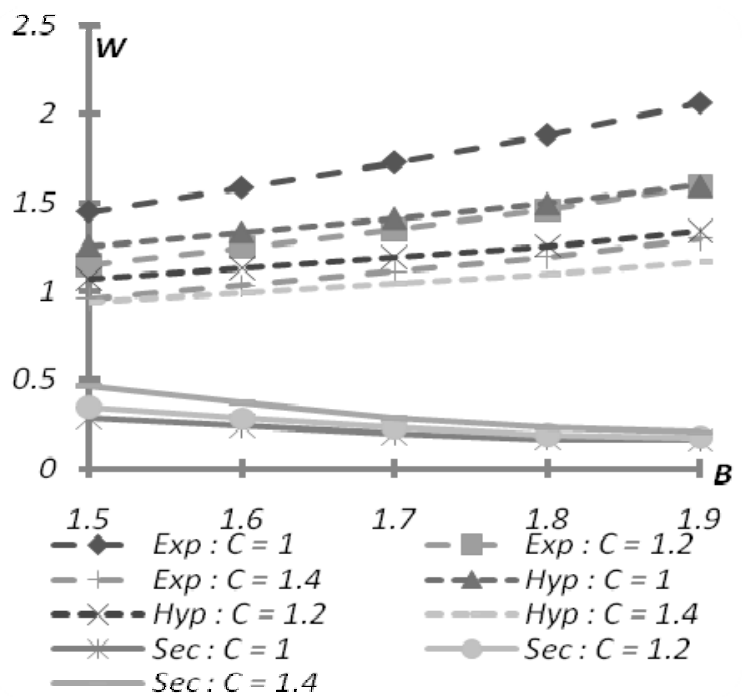

Figure 10. Variation of Load carrying capacity with respect to $B$ and $C$. 


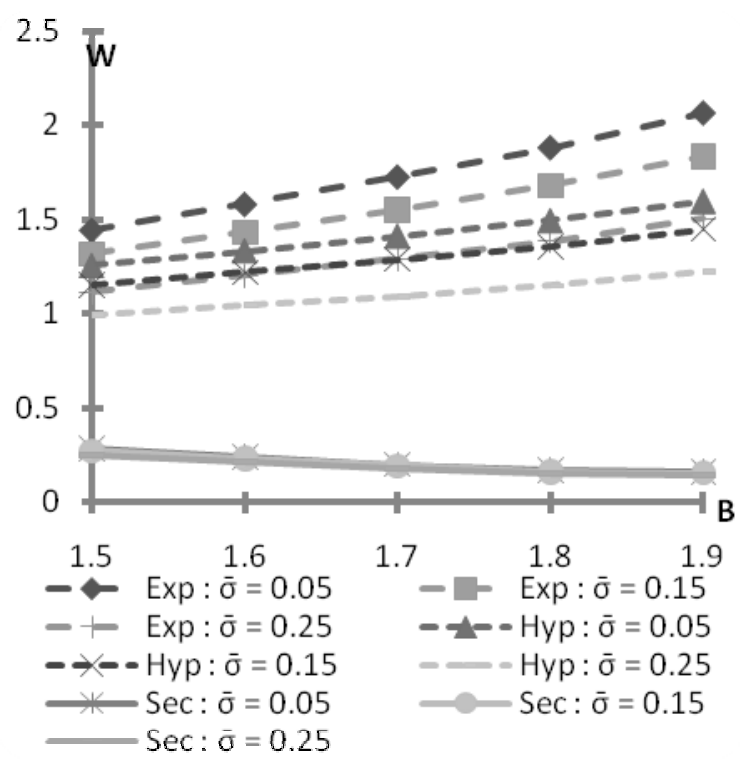

Figure 11. Variation of Load carrying capacity with respect to $B$ and $\bar{\sigma}$.

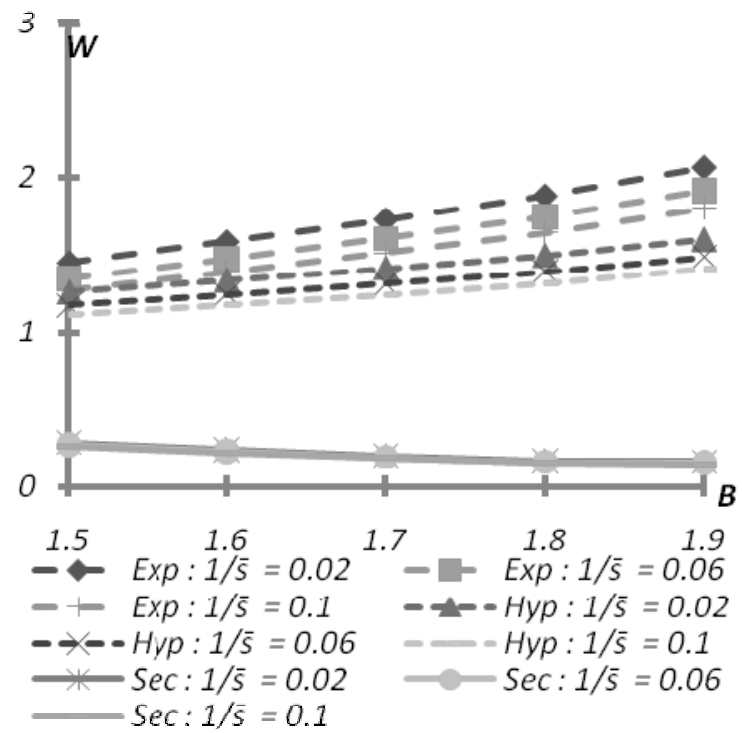

Figure 12. Variation of Load carrying capacity with respect to $B$ and $1 / s^{-}$.

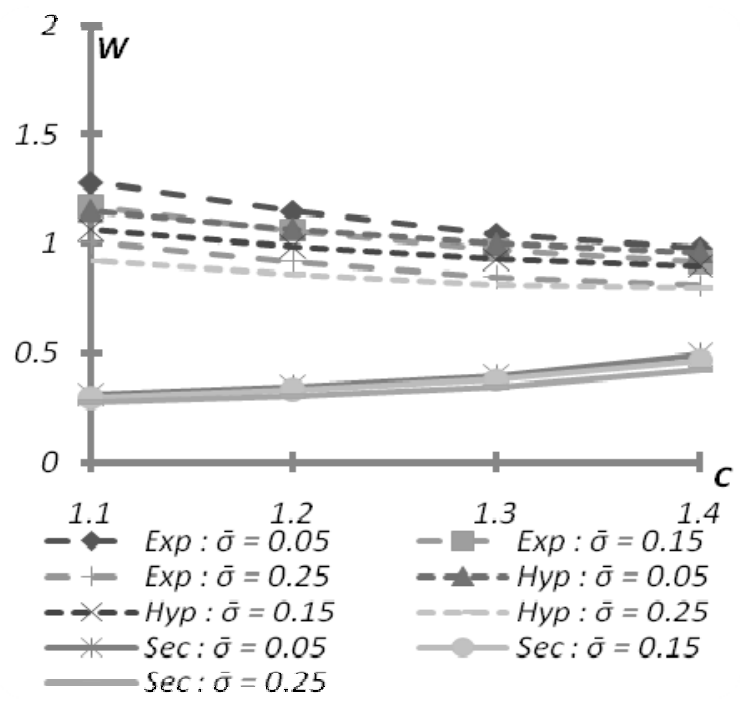

Figure 13. Variation of Load carrying capacity with respect to $C$ and $\bar{\sigma}$.

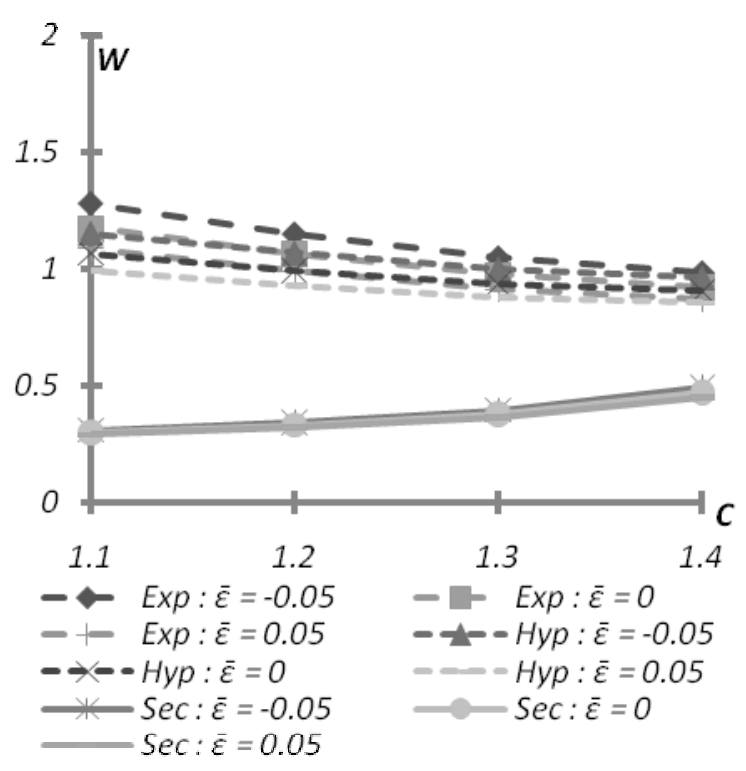

Figure 14. Variation of Load carrying capacity with respect to $C$ and $\bar{\varepsilon}$.

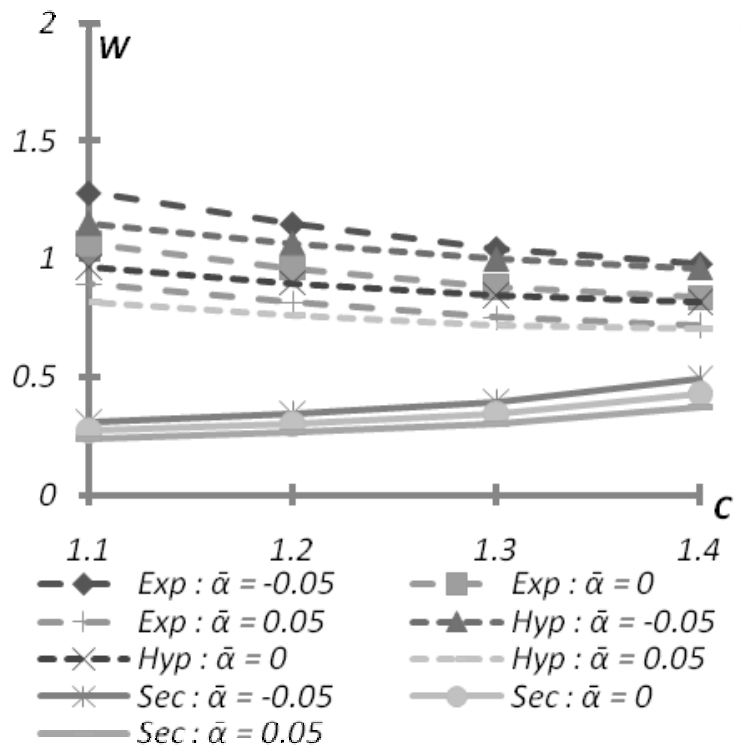

Figure 15. Variation of Load carrying capacity with respect to $C$ and $\bar{\alpha}$.

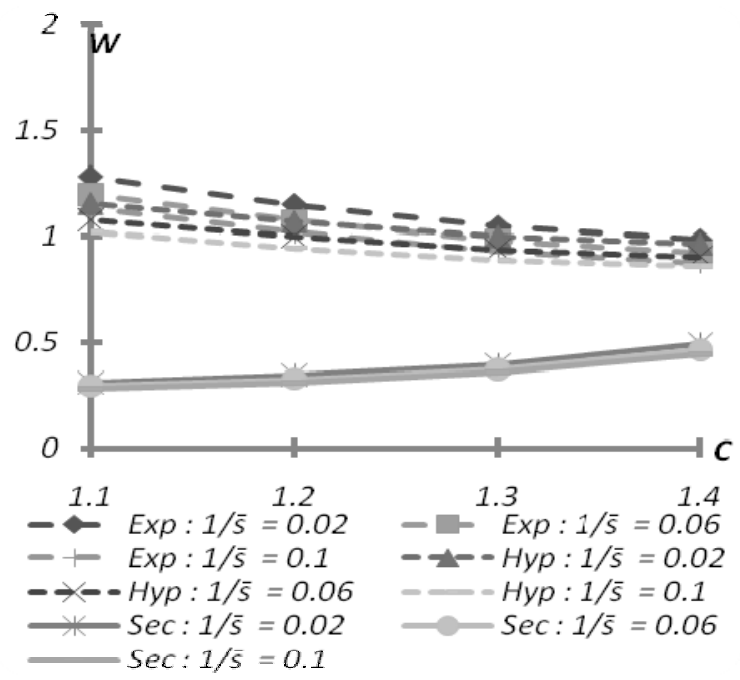

Figure 16. Variation of Load carrying capacity with respect to $C$ and $1 / \bar{s}$. 
The standard deviation associated with roughness decreases the load carrying capacity in all the cases. However, this effect is negligible for secant shape bearing system (Figures 17-19).

The positively skewed roughness decreases the load carrying capacity while the load carrying capacity gets enhanced by the negatively skewed roughness, as can be seen form Figures 20-21. Lastly, the trends of load carrying capacity with respect to variance are akin to that of skewness (Figure 22). Therefore, the combined effect of variance (-ve) and negatively skewed roughness becomes crucial for improving the performance of the bearing system.

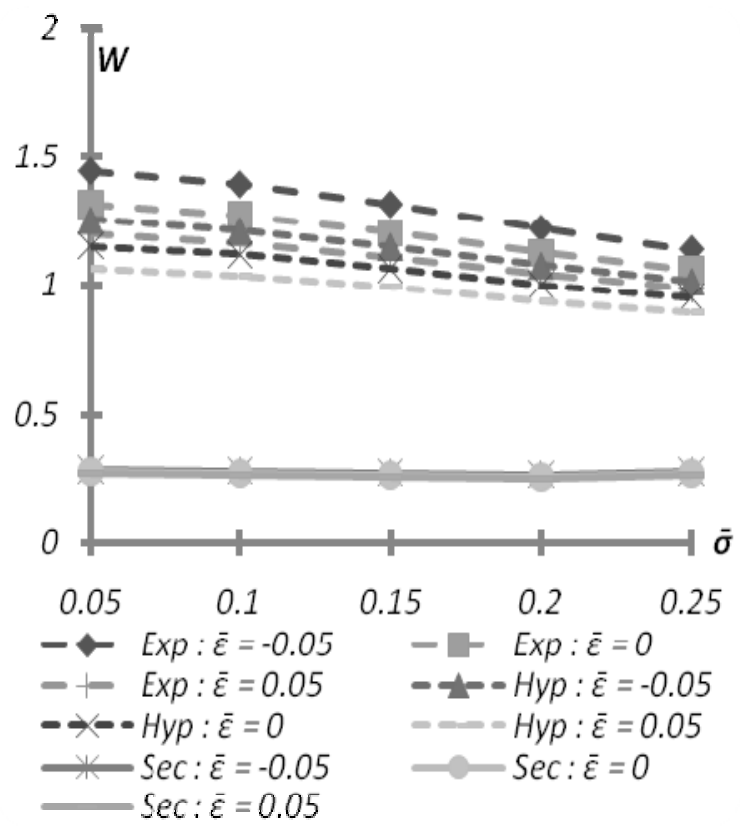

Figure 17. Variation of Load carrying capacity with respect to $\bar{\sigma}$ and $\bar{\varepsilon}$.

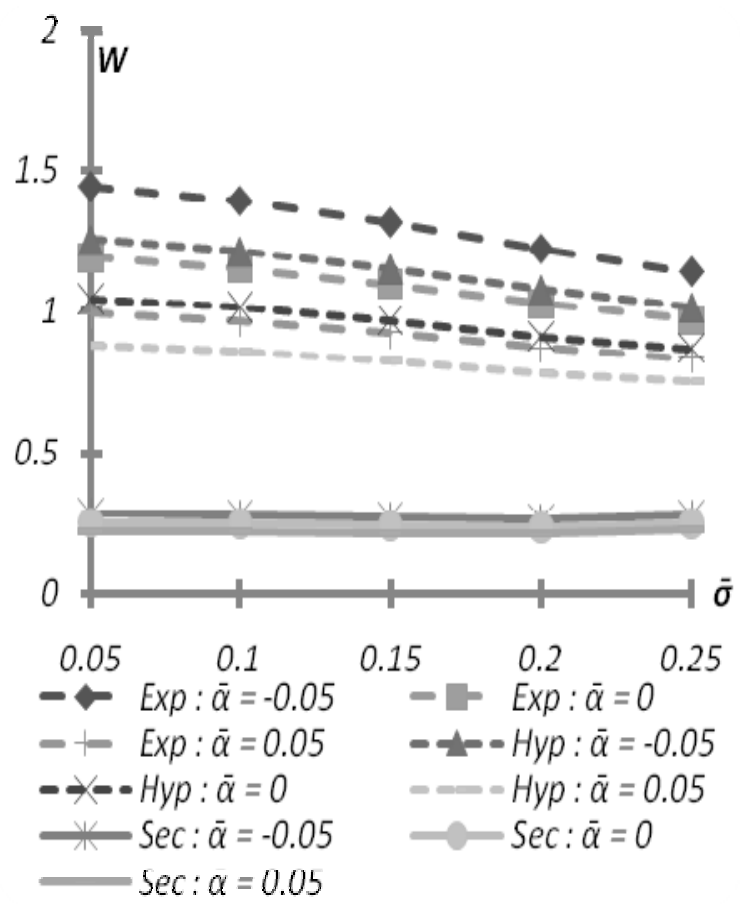

Figure 18. Variation of Load carrying capacity with respect to $\bar{\sigma}$ and $\bar{\alpha}$.

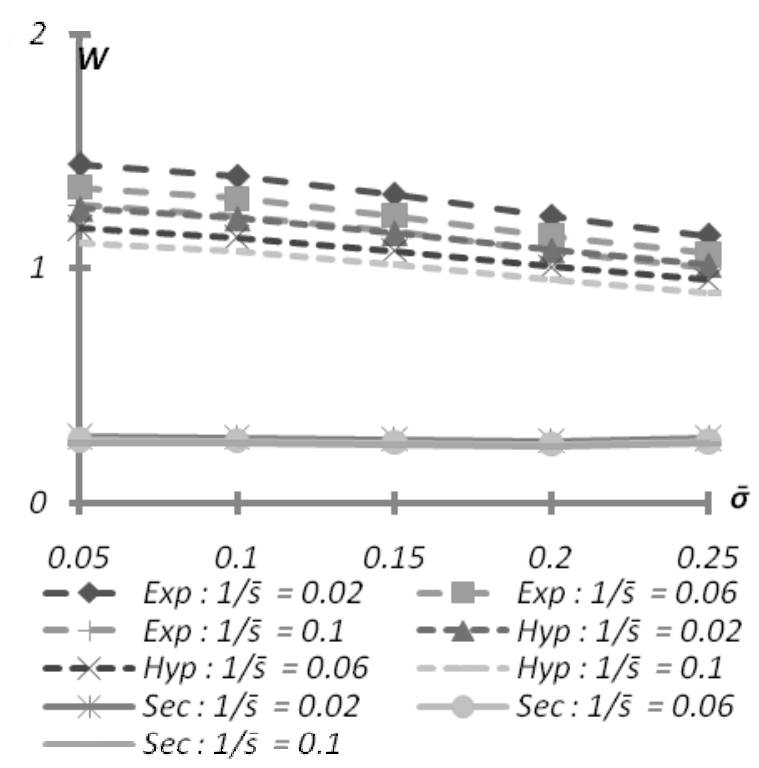

Figure 19. Variation of Load carrying capacity with respect to $\bar{\sigma}$ and $1 / \bar{s}$.

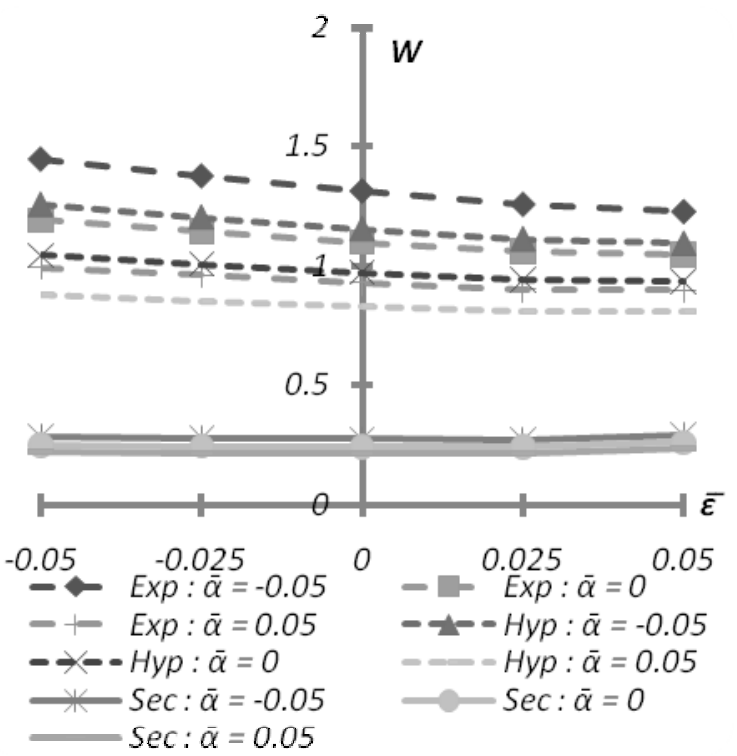

Figure 20. Variation of Load carrying capacity with respect to $\bar{\varepsilon}$ and $\bar{\alpha}$.

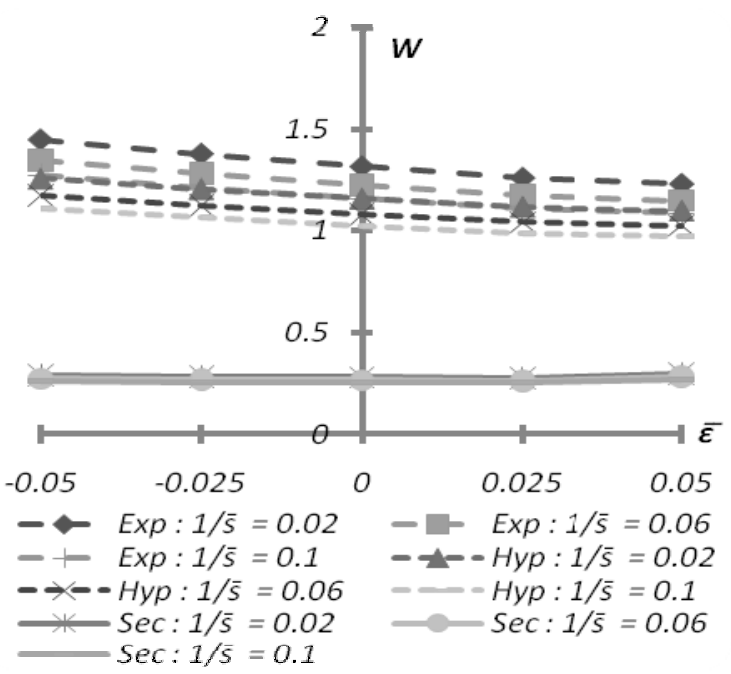

Figure 21. Variation of Load carrying capacity with respect to $\bar{\varepsilon}$ and $1 / \bar{s}$. 


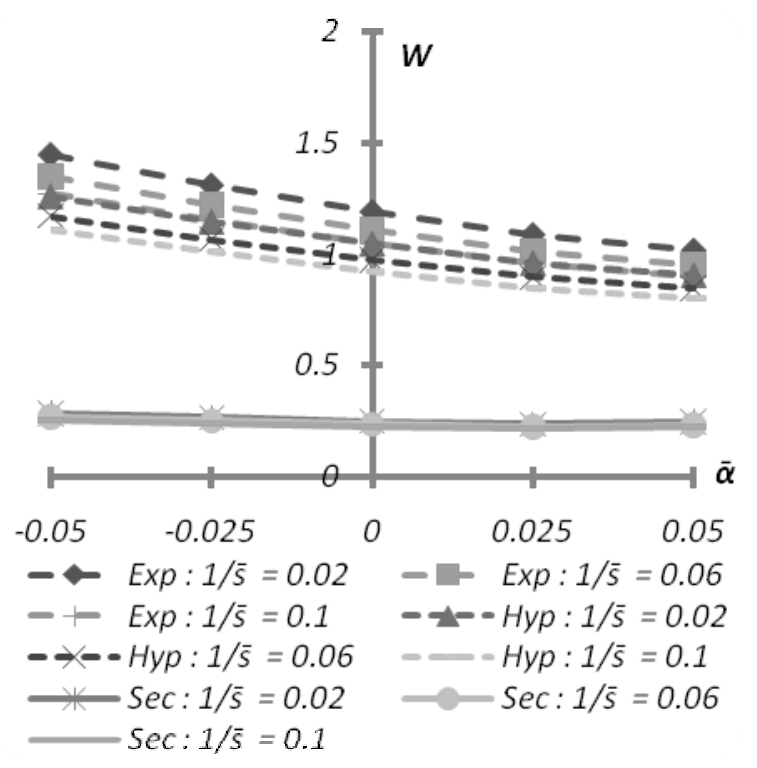

Figure 22. Variation of Load carrying capacity with respect to $\bar{\alpha}$ and $1 / \bar{s}$.

It is revealed that the effect of slip is more in the case of lower plate's curvature parameter for all the shapes.

A close scrutiny of some of the graphs tends to suggest that the combined effect of standard deviation, slip parameter and the material constant parameter is at the most nominal for the case of secant shape bearing system.

It is noticed that the trends of load with respect to curvature parameters for exponential and parabolic shapes are almost opposite to that of secant shape bearing system.

\section{CONCLUSION}

It is clearly visible that Jenkins model modifies the performance in the case of Neuringer- Rosensweig model for all the shapes. The roughness is required to be accounted for while designing the bearing system even if Jenkins model is adopted as the material constant and slip parameter cause reduced load carrying capacity. However, for an improved performance the slip parameter deserves to be kept at minimum. Considering all the aspects it is revealed that the exponential bearing scores over the other two bearing systems. It is also appealing to note that this type of bearing system supports certain amount of load even in the absence of flow unlike the case of conventional lubricant based bearing system.

\section{ACKNOWLEDGEMENT}

The authors acknowledge with thanks the fruitful comments and suggestions of reviewers.Further, the swift and appropriate action of the editor is gratefully acknowledged.

\section{REFERENCES}

[1] Goldowsky, M.: New methods for sealing, filtering and lubricating with magnetic fluids, IEEE T. Magn. Mag., Vol. 16, pp. 382-386, 1980.
[2] Rosensweig, R.E.: Ferro hydrodynamics, Cambridge University Press, Cambridge, 1985.

[3] Shukla, J.B. and Kumar, D.: A theory for ferromagnetic lubrication, J. Magn. Magn. Mater., Vol. 65, pp. 375-378, 1987.

[4] Raj, K.B., Moskowitz, V. and Casciari, R.: Advances in ferrofluid technology, J. Magn. Magn. Mater., Vol. 149, pp. 174-180, 1995.

[5] Odenbach, S.: Ferrofluids-magnetically controlled suspensions, Colloids Surf. A, Vol. 217, pp. 171178, 2003.

[6] Scherer, C. and Neto, A. M. Figueiredo: Ferrofluids: Properties and Applications, Brazilian Journal of Physics, Vol. 35, No. 3A, pp. 718-727, 2005.

[7] Odenbach, S.: Colloidal Magnetic Fluids: Basics, Development and Application of Ferrofluids, Springer, Berlin, 2009.

[8] Deheri, G.M. and Patel, J.R.: Magnetic fluid based squeeze film in a rough Porous parallel plate slider bearing, Annals of Faculty Engg. Hunedoara-Int. Jour. of Engg., Vol. 9, No. 3, pp.443-448, 2011.

[9] Agrawal, V.K.: Magnetic-fluid-based porous inclined slider bearing, Wear, Vol. 151, pp. 123128, 1991.

[10] Ram, P. and Verma, P.D.S.: Ferrofliuid lubrication in porous inclined slider bearing, Indian Journal of Pure and Applied Mathematics, Vol. 30, No. 12, pp. 1273-1281, 1999.

[11] Shah, R.C. and Bhat, M.V.: Ferrofliuid lubrication in porous inclined slider bearing with velocity slip, Int. J. Mech. Sci., Vol. 44, pp. 2495-2502, 2002.

[12] Ahmad, N. and Singh, J.P.: Magnetic Fluid lubrication of porous-pivoted slider bearing with slip velocity, Journal of Engineering Tribology, Vol. 221, pp. 609-613, 2007.

[13] Archibald, F.R.: Load capacity and time relations for squeeze films. Trans. ASME, Vol. 78A, pp. 231-245, 1956.

[14] Cameron, A.: The Principles of Lubrication. Longmans, London, 1966.

[15] Prakash, J. and Vij, S.K.: Load capacity and time height relation between porous plates, Wear, Vol. 24, pp. 309-322, 1973.

[16] Hamrock, B.J.: Fundamentals of Fluid Film Lubrication, McGraw-Hill, Inc., New York, 1994.

[17] Bhat, M.V.: Lubrication with a Magnetic fluid, Team Spirit (India) Pvt. Ltd, India, 2003.

[18] Murti, P.R.K.: Squeeze films in curved circular plates, Journal of Tribology, Vol. 97, No. 4, pp. 650-652, 1975.

[19] Gupta, J.L. and Vora, K.H.: Analysis of squeeze film between curved annular plates, J. Lubr. Technol. Trans. ASME, Vol. 102, pp. 48-59, 1980.

[20] Ajwaliya, M.B.: On certain theoretical aspects of lubrication. Dissertation, Sardar Patel University Vallabh Vidyanagar, India, 1984. 
[21] Deheri, G. M. and Abhangi, N. D.: Squeeze film based on magnetic fluid in curved rough circular plates, Journal of Engineering annals of Faculty of engineering Hunedoara, Vol. 6, No. 2, pp. 95-106, 2008.

[22] Shimpi, M.E. and Deheri, G.M.: Ferrofluid Lubrication of Rotating Curved Rough Porous Circular Plates and Effect of Bearing's Deformation, Arabian Journal for Science and Engineering, Vol. 38, No. 10, pp. 2865-2874, 2013.

[23] Beavers, G.S. and Joseph, D.D.: Boundary conditions at a naturally permeable wall, Journal of Fluid Mechanics, Vol. 30, pp. 197-207, 1967.

[24] Patel, K.C.: The hydrodynamic squeeze film between porous circular disks with velocity slip, Wear, Vol. 5, pp. 275-281, 1980.

[25] Thompson, P.A. and Troian, S.M.: A general boundary condition for liquid flow at solid surfaces, Nature, Vol. 389, pp. 360-362, 1997.

[26]Zhu, Y. and Granick, S.: Rate-Dependent Slip of Newtonian Liquid at Smooth Surfaces, Physical review letters, Vol. 87, No. 9, pp. 096105-1-4, 2001.

[27] Spikes, H. and Granick, S.: Equation for Slip of Simple Liquids at Smooth Solid Surfaces, Langmuir, Vol. 19, No. 12, pp. 5065-5071, 2003.

[28] Salant, R.F. and Fortier, A.E.: Numerical Analysis of a Slider Bearing with a Heterogeneous Slip/NoSlip Surface, Tribology Transactions, Vol. 47, No. 3, pp. 328-334, 2004

[29] Wu, C.W., Ma, G.J., Zhou, P. and Wu, C.D.: Low Friction and High Load Support Capacity of Slider Bearing With a Mixed Slip Surface, Journal of Tribology, Vol. 128, No. 4, pp. 904-907, 2006.

[30] Patel, N.D. and Deheri, G.M.: Effect of surface roughness on the performance of a magnetic fluid based parallel plate porous slider bearing with slip velocity, J. Serb. Soc. Comput. Mech.,Vol. 5, No. 1, pp. 104-118, 2011

[31] Wang, L.L., Lu, C.H., Wang, M. and Fu, W.X.: The Numerical Analysis of The Radial Sleeve Bearing With Combined Surface Slip, Tribology International, Vol. 47, pp. 100-104, 2012.

[32] Rao, R.R., Gouthami, K. and Kumar, J. V.: Effect of velocity-slip and viscosity variation in squeeze film lubrication of two circular plates, Tribology in industry, Vol. 35, No. 1, pp. 51-60, 2013.

[33] Patel, J.R., and Deheri, G.M.: Slip Velocity and Roughness Effect on Magnetic Fluid Based Infinitely Long Bearings, Proceedings of International Conference on Advances in Tribology and Engineering Systems Lecture Notes in Mechanical Engineering, Springer India, pp. 97109, 2014.

[34] Christensen, H. and Tonder, K.C.: Tribology of rough surfaces: stochastic models of hydrodynamic lubrication, SINTEF, Report No.10, pp. 69-18, 1969a.
[35] Christensen, H. and Tonder, K.C.: Tribology of rough surfaces: parametric study and comparison of lubrication models, SINTEF, Report No.22, pp. 69$18,1969 b$.

[36]Christensen, H. and Tonder, K.C.: The hydrodynamic lubrication of rough bearing surfaces of finite width, ASME-ASLE Lubrication Conference. Cincinnati. OH. Paper no. 70-lub-7, October 12-15, 1970.

[37] Tzeng, S.T. and Saibel, E.A.: Surface roughness effect on slider bearing lubrication, Trans. ASME, J. Lubrication Technology. 10. pp.334-338, 1967.

[38] Ting, L.: Engagement behavior of lubricated porous annular disks. Part I: Squeeze film phase -- surface roughness and elastic deformation effects, Wear, Vol. 34, No. 2, pp. 159-172, 1975.

[39] Prakash, J. and Tiwari, K.: Lubrication of a Porous Bearing with Surface Corrugations, Jour. of Tribology, Tech. Vol. 104, No. 1, pp. 127-134, 1982.

[40] Guha, S.: Analysis of dynamic characteristics of hydrodynamic journal bearings with isotropic roughness effects, Wear, Vol. 167, No. 2, pp. 173179, 1993.

[41] Gupta, J.L. and Deheri, G.M.: Effect of roughness on the behavior of squeeze film in a spherical bearing, Tribol Trans., Vol. 39, pp. 99-102, 1996.

[42] Naduvinamani, N.B., Fathima, S.T. and Hiremath, P.S. Hydrodynamic lubrication rough Slider bearings with couple stress fluids, Tribology International, Vol. 36, No. 12, pp. 949-959, 2003.

[43] Deheri, G.M., Andharia, P.I. and Patel, R. M.: Longitudinally rough slider bearings with Squeeze film formed by a magnetic fluid, Industrial Lubrication and Tribology, Vol. 56, No. 3, pp. 177 $187,2004$.

[44] Chiang, H.L., Hsu, C.H. and Lin, J.R.: Lubrication performance of finite journal bearings considering effects of couple stresses and surface roughness, Tribology International, Vol. 37, No. 4, pp. 297-307, 2004.

[45] Deheri, G.M., Patel, H.C. and Patel, R.M.: Behavior of Magnetic Fluid-based Squeeze Film between Porous Circular Plates with Porous Matrix of Variable Thickness, International Journal of Fluid Mechanics Research, Vol. 34, No. 6, pp. 506514, 2007.

[46] Bujurke, N. M., Basti, D. P. and Kudenatti, R. B.: Surface roughness effects on squeeze film behaviour in porous circular disks with couple stress fluid, Transp Porous Med, Vol. 71, pp. 185197, 2008.

[47] Patel, H.C., Deheri, G.M. and Patel, R.M.: Magnetic fluid-based squeeze film between porous rotating rough circular plates, Industrial Lubrication and Tribology, Vol. 61, No. 3, pp. 140-145, 2009.

[48] Shimpi, M.E. and Deheri, G.M.: Surface roughness and elastic deformation effects on the behaviour of the magnetic fluid based squeeze film between 
rotating porous circular plates with concentric circular pockets, Tribology in Industry, Vol. 32, No. 2, pp. 21-30, 2010.

[49] Patel, R.M., Deheri, G.M. and Patel, H.C.: Effect of surface roughness on the behavior of a magnetic fluid based squeeze film between circular plates with porous matrix of variable thickness, Acta Polytechnica Hungarica, Vol. 8, No. 5, pp. 171190, 2011.

[50] Patel, J.R. and Deheri, G.M.: Shliomis Model Based Ferrofluid Lubrication of Squeeze Film in Rotating Rough Curved Circular Disks with Assorted Porous Structures, American Journal of Industrial Engineering, Vol. 1, No. 3,pp. 51-61, 2013.

[51] Patel, J.R. and Deheri, G.M.: Theoretical study of Shliomis model based magnetic squeeze film in rough curved annular plates with assorted porous structures, FME Transactions, Vol. 42, No. 1, pp. 56-66, 2014.

[52] Abhangi, N.D. and Deheri, G.M.: Numerical modeling of squeeze film performance between rotating transversely rough curved circular plates under the presence of a magnetic fluid lubricant," ISRN Mechanical Engineering, Vol. 2012. Article ID 873481, 2012.

[53] Patel, J.R. and Deheri, G.M.: Shliomis model based magnetic fluid lubrication of a squeeze film in rotating rough curved circular plates, Caribbean Journal of Science and Technology, Vol. 1, pp. 138-150, 2013.

[54] Patel, J.R. and Deheri, G.M.: Shliomis model-based magnetic squeeze film in rotating rough curved circular plates: a comparison of two different porous structures, Int. J. Computational Materials Science and Surface Engineering, Vol. 6, No. 1, pp.29-49, 2014.

[55] Jenkins, J.T.: A theory of magnetic fluids, Arch. Rational Mech. Anal., Vol. 46, pp. 42-60, 1972.

[56] Prajapati, B. L.: On Certain Theoretical Studies in Hydrodynamic and Electro-magneto hydrodynamic
Lubrication, Ph. D. Thesis: S.P. University, Vallabh Vidya- Nagar, 1995.

[57]Deheri, G.M., Andharia, P.I. and Patel, R.M.: Transversely rough slider bearings with squeeze film formed by a magnetic fluid," Int. J. of Applied Mechanics and Engineering, Vol. 10, No. 1, pp. 53$76,2005$.

\section{ЏЕНКИНСОВ МОДЕЛ ЗАСНОВАН НА МАГНЕТНОМ ФЛУИДУ БАЗИРАНОМ НА СТИСНУТОМ ФИЛМУ КОД САВИЈЕНИХ ХРАПАВИХ ОКРУГЛИХ ПЛОЧА СА АСПЕКТА БРЗИНЕ КЛИЗАЊА: ПОРЕЪЕЊЕ ОБЛИКА}

\section{Jimit R. Patel, G. M. Deheri}

У раду се упоређују перформансе Џенкинсовог модела заснованог на магнетном флуиду базираном на стиснутом филму код савијених храпавих округлих плоча са аспекта брзине клизања, при различитим облицима површине. Поређење је вршено код три различита облика површине (експоненцијални, хиперболични и секантни). За анализу утицаја клизања коришћен је Биверсов и Џозефов модел. Кристенсенов и Тондеров модел просечних статистичких вредности је усвојен за проучавање утицаја површинских неравнина. Решава се генералисана једначина Рејнолдсовог типа да би се добила дистрибуција притиска која се користи за израчунавање капацитета оптерећења. Резултати приказани у облику графика потврђују да Џенкинсов модел модификује перформансе Нојрингер-Росенсвајговог модела. Џенкинсов модел заснован на подмазивању гвозденим флуидом је донекле напреднији јер редукује неповољан утицај храпавости и брзине клизања, што је у већој мери изражено код експоненцијалног облика. Занимљиво је приметити да је код експоненцијалног облика комбиновани утицај магнетизма и негативно укрштене храпавости већи, чак и код већих вредности параметра клизања. 